\title{
Comparison of cell-surface L-amino acid oxidases from several marine phytoplankton
}

\author{
Brian Palenik*, François M. M. Morel \\ Ralph M. Parsons Laboratory, Building 48-425, M.I.T. Cambridge, Massachusetts 02139, USA
}

\begin{abstract}
Phytoplankton possess cell-surface oxidases that oxidize amino acids and primary amines to produce extracellular $\mathrm{H}_{2} \mathrm{O}_{2}, \mathrm{NH}_{4}{ }^{+}$, and $\alpha$-keto acids (from amino acids) or aldehydes (from primary amines). The $\mathrm{NH}_{4}{ }^{+}$is subsequently taken up and used for growth. A survey of marine phytoplankton shows that at least 3 genera possess cell-surface L-amino acid oxidases: Pleurochrysis and Prymnesium (prymnesiophytes), and Amphidinium (a dinoflagellate). These enzymes are quite similar, with halfsaturation concentrations of $\mathrm{ca} 0.1$ to $0.5 \mu \mathrm{M}$, but differ in their inhibition by the nonspecific protease proteinase $K$, and a detergent, lithium dodecyl sulfate.
\end{abstract}

\section{INTRODUCTION}

Phytoplankton have long been known to take up amino acids from their environment (reviewed by Flynn \& Butler 1986). The marine phytoplankton Pleurochrysis carterae, however, was recently shown to utilize amino acids as a nitrogen source without relying on amino acid uptake (Palenik \& Morel 1990). This organism and other Pleurochrysis (previously Hymenomonas) species oxidize amino acids at their cell surfaces to generate $\mathrm{NH}_{4}{ }^{+}, \mathrm{H}_{2} \mathrm{O}_{2}$ and an $\alpha$-keto acid. Only the ammonium is then transported into the cell. The enzyme responsible for this reaction is an $\mathrm{L}$ amino acid oxidase, or more generally a cell-surface deaminase. Its function is analogous to the well-known cell-surface phosphatases that make organic forms of phosphorus available to phytoplankton by converting them to inorganic phosphate (Kuenzler \& Perras 1965).

The presence of cell-surface L-amino acid oxidases in the environment has important implications for the cycling of hydrogen peroxide, $\alpha$-keto acids, amino acids, and nitrogen in general. In particular, it reopens the issue of bacterial dominance of amino acid cycling, because field measurements of amino acid turnover would typically miss the presence of amino acid oxidases. In addition, the presence of L-amino acid oxidases suggests a more active role for phytoplankton in remineralizing

\footnotetext{
- Present address: Dept of Molecular Genetics and Cell Biology, University of Chicago, Chicago, lllinois 60637, USA.

nitrogen. To begin to understand the ecological significance of L-amino acid oxidases, an initial survey of their presence in phytoplankton was made and is reported here. Out of 10 phytoplankton genera examined, 3 Pleurochrysis and Prymensium (prymnesiophytes), and Amphidinium (a dinoflagellate) - were found to possess cell-surface L-amino acid oxidases.

\section{MATERIALS AND METHODS}

Materials. Pleurochrysis carterae (clone COCCOII), Prymnesium parvum (PRYM), Prymnesium calathiferum (CHANG1), Amphidinium carterae (AMPHI), Amphidinium operculatum (AMPHID), Symbiodinium microadriaticum (HIPP), Pavlova gyrans (MPPAV), and Micromonas pusilla (DW8) were obtained from the Center for Culture of Marine Phytoplankton (CCMP), Bigelow Laboratories, West Boothbay Harbor, Maine 04575, USA. A Nannochloris-like isolate (ISB $\star$ ) was obtained from R. Olson (Woods Hole Oceanographic Institution, Massachusetts, USA). Emiliania Huxleyi (12-1) and Thalassiosira weissflogii (ACTIN) were already in culture, but can be obtained from CCMP. A Tetraselmis species (4B-9) was isolated from the Sargasso Sea at $32^{\circ} \mathrm{N}, 62^{\circ} \mathrm{W}$. Aiptasia pallida, a marine and brackish water anenome, was obtained from Carolina Biological Supply House (USA) and maintained according to accompanying instructions.

Amino acids, bovine serum albumin (BSA), pyruvate, and hydroxyphenylpropionic acid were obtained from 
Sigma Chemical or Aldrich. The highest purity stocks available were obtained, typically 98 to $99+\%$ pure. Horseradish peroxidase Type VI was obtained from Sigma. 2,4-Dinitrophenylhydrazine was obtained from Sigma and recrystallized before use (Kieber \& Mopper 1986).

Methods. Cultures were maintained in $\mathrm{f} / 10$ without silica (Guillard \& Ryther 1962) enriched coastal (Woods Hole) or occasionally Sargasso seawater. The seawater was $0.45 \mu \mathrm{m}$ filtered and sterilized by microwaving (Keller et al, 1988), autoclaving, or pasteurization (Brand et al. 1983) with little obvious effect on enzyme activities. Cultures were maintained under constant fluorescent (cool white) light at about 18 to $20^{\circ} \mathrm{C}$. Nitrogen-limited cultures were obtained by leaving out nitrogen (nitrate) additions or making small (f/200) additions and using the cells after growth stopped. Growth of cultures was followed by chlorophyll fluorescence (shown in relative fluorescence units, RFU) on a Turner fluorometer and cell counts were measured using a Coulter cell counter. Bacterial or fungal contamination was typically monitored with Difco marine broth 2216, and occasionally by plating cultures on $\mathrm{f} / 10$ enriched agar or by microscopic examination. The cultures which are the major focus of this study (PRYM, COCCOII, and AMPHID) were maintained and studied while free of bacterial contamination. Of the other cultures listed above, MPPAV, ACTIN, and AMPHI were also axenic, while the others were bacterized.

Production of $\alpha$-keto acid by cultures was assayed using the method of Kieber \& Mopper (1986) as described in Palenik \& Morel (1990). Simultaneously, $\mathrm{H}_{2} \mathrm{O}_{2}$ production was measured by the horseradish peroxidase catalyzed oxidation by $\mathrm{H}_{2} \mathrm{O}_{2}$ of hydroxyphenylpropionic acid to a fluorescent dimer. In a 'nontrapping' mode this was done by taking $2 \mathrm{ml}$ subsamples at intervals, diluting to $20 \mathrm{ml}$ with low $\mathrm{H}_{2} \mathrm{O}_{2}$ Sargasso seawater, adding $0.5 \mathrm{ml}$ hydroxyphenylpropionic acid ( $2 \mathrm{mM}$ stock) and $10 \mu \mathrm{l}$ freshly prepared horseradish peroxidase (about $4 \mathrm{mg} \mathrm{ml}^{-1}$ stock) and measuring the fluorescence (proportional to $\mathrm{H}_{2} \mathrm{O}_{2}$ ) of the sample. $\mathrm{H}_{2} \mathrm{O}_{2}$ was also measured in a 'trapping' mode by removing a $20 \mathrm{ml}$ sample at the beginning of the experiment, adding the $\mathrm{H}_{2} \mathrm{O}_{2}$ reagents, and following fluorescence $\left(\mathrm{H}_{2} \mathrm{O}_{2}\right)$ with time. In both cases fluorescence $\left(\mathrm{H}_{2} \mathrm{O}_{2}\right)$ was measured on a Turner fluorometer (Palenik \& Morel 1988). For other assays of $\mathrm{H}_{2} \mathrm{O}_{2}$ production, the measurements were made with a PerkinElmer LS-5 fluorometer as in Palenik \& Morel (1990).

The symbiotic dinoflagellates (Symbiodinium sp.) in Aiptasia pallida were isolated based on the procedures of McLaughlin \& Zahl (1959). The tentacles of 4 hosts were briefly homogenized in a tissue grinder and filtered through cheesecloth. The material was diluted with $0.2 \mu \mathrm{m}$ filtered Sargasso seawater and centrifuged to collect the cells. The cells were resuspended and filtered through $25 \mu \mathrm{m}$ Nitex. The cells were centrifuged and the pellet again resuspended in seawater. The cells were then assayed for $\mathrm{H}_{2} \mathrm{O}_{2}$ production (72000 cells $\mathrm{ml}^{-1}$ ) in the presence and absence of Lalanine, and, as a blank, in the absence of HRP. A slow rate of nonspecific fluoresence increase was observed.

\section{RESULTS}

A range of marine phytoplankton were assayed for Lamino acid oxidase activity. The following organisms did not show L-amino acid oxidase activity under nitrogen-limited or other conditions tested: Thalassiosira weissflogii (ACTIN), a diatom; Micromonas pusilla (DW8) and Tetraselmis sp. (4B-9), prasinophytes; Nannochloris-like isolate (ISB $\star$ ), probably a chlorophyte; Pavlova gyrans (MPPAV) and Emiliania huxleyi (12-1), prymnesiophytes. However, several phytoplankton showed oxidase activity and were studied in more detail: Amphidinium carterae (AMPHI) and A. operculatum (or klebsii, AMPHID), dinoflagellates; and Prymnesium parvum (PRYM) and $P$. calathiferum (CHANG1), prymnesiophytes.

Because AMPHID was originally isolated as an endosymbiont of the jellyfish, Cassiopeia, the presence of L-amino acid oxidase was investigated in members of the other major group of endosymbiotic dinoflagellates, Symbiodinium sp. The enzyme was not found in Symbiodinium microadriaticum (clone HIPP), an organism in culture. It was also not found in dinoflagellates (Symbiodinium sp.) freshly isolated from an anenome, Aiptasia pallida (see Materials and methods'). Although genetic differences exist between Symbiodinium species, these results suggest that $\mathrm{L}$ amino acid oxidases are not present in this genus.

When certain L-amino acids were added to preconditioned AMPHID, PRYM, or COCCOII cultures, $\mathrm{H}_{2} \mathrm{O}_{2}$, $\mathrm{NH}_{4}{ }^{+}$, and an $\alpha$-keto acid were produced due to the presence of a cell-surface L-amino acid oxidase (Palenik \& Morel 1990). For example, when $1 \mu \mathrm{M} \mathrm{L}$ alanine was added to a nitrogen-limited culture of Prymnesium parvum (PRYM), $\mathrm{H}_{2} \mathrm{O}_{2}$ and pyruvate were produced in a 1.1 molar ratio when the $\mathrm{H}_{2} \mathrm{O}_{2}$ produced was 'trapped' (Fig. 1, see 'Materials and methods'). When $\mathrm{H}_{2} \mathrm{O}_{2}$ was measured without trapping, less $\mathrm{H}_{2} \mathrm{O}_{2}$ was measured due to the breakdown of $\mathrm{H}_{2} \mathrm{O}_{2}$ in the culture. A similar result was seen for a $0.5 \mu \mathrm{M}$ addition of L-alanine to a nitrogen-limited AMPHID culture (Fig 1). In this case, hydrogen peroxide trapping was begun at $20 \mathrm{~min}$, so some $\mathrm{H}_{2} \mathrm{O}_{2}$ was initially lost. $\mathrm{H}_{2} \mathrm{O}_{2}$ decomposition was apparently more rapid than for PRYM cultures. Pyruvate and $\mathrm{H}_{2} \mathrm{O}_{2}$ production from $L$ - 


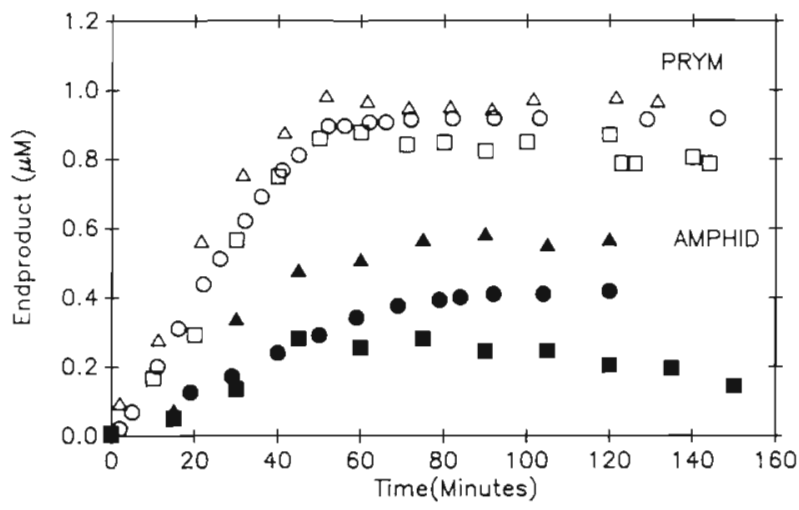

Fig. 1 Hydrogen peroxide and pyruvate production from Lalanine. After addition of $1 \mu \mathrm{M} \mathrm{L}$-alanine to nitrogen-limited PRYM culture (88400 cells $\left.\mathrm{ml}^{-1}\right):(\Delta)$ pyruvate; (0) $\mathrm{H}_{2} \mathrm{O}_{2}$, trapped; (ם) $\mathrm{H}_{2} \mathrm{O}_{2}$, untrapped. After addition of $0.5 \mu \mathrm{M} \mathrm{L}$ alanine to nitrogen-limited AMPHID culture $(41600$ cells

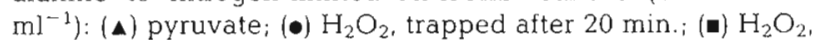
untrapped

alanine has been reported previously for COCCOII (Palenik \& Morel 1990).

The third product of an amino acid oxidase is $\mathrm{NH}_{4}{ }^{+}$, which is taken up and used for growth. Thus we would expect organisms to grow on amino acids as a nitrogen source which are substrates of the oxidase. When 50 $\mu \mathrm{M}$ sterile filtered L-aspartic acid and L-alanine were added to nitrogen-limited cultures of PRYM (Fig. 2) and AMPHID (Fig. 3) the organisms began to grow. Growth on these 2 amino acids was slower than on ammonia, particularly for AMPHID. L-serine supported some slow growth in both organisms, but was a better source of nitrogen for PRYM. As discussed later these results paralleled the enyzyme kinetics for these substrates.

Neither PRYM nor AMPHID grew on a protein, bovine serum albumin (BSA), at $10 \mathrm{mg} \mathrm{l}^{-1}$ as a nitrogen source (Fig. 2 and 3). Pleurochrysis carterae, various

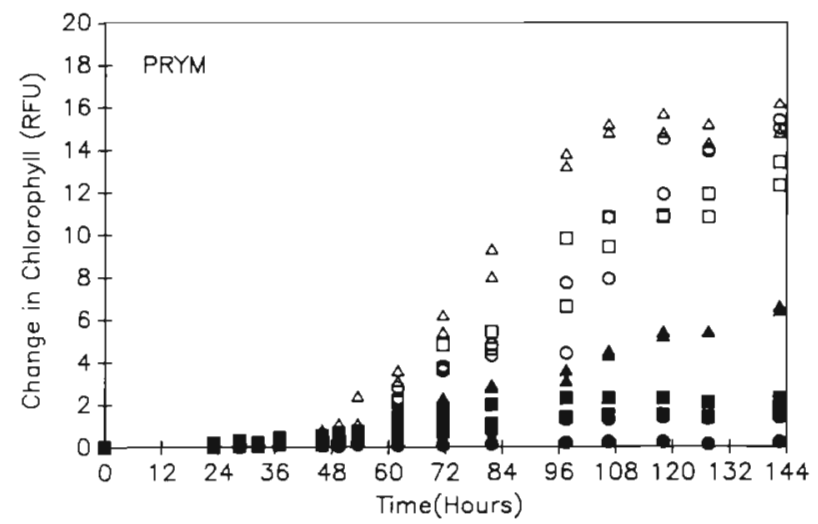

Fig. 2. Growth of PRYM after $50 \mu \mathrm{M}$ amino acid or $0.01 \mathrm{mg}$ $\mathrm{ml}^{-1} \mathrm{BSA}$ additions to nitrogen-limited cultures (as change in chlorophyll fluorescence in a culture tube from its initial value

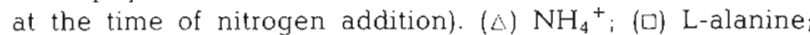

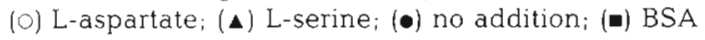

clones of which utilize amino acids for growth (Wheeler et al. 1974, Turner 1979, Palenik \& Morel 1990), also could not grow on BSA (Fig. 4). Interestingly, when bacteria were added to axenic cultures of COCCOII, this organism could grow on BSA as a nitrogen source (Fig. 4). These bacteria were taken from a bacterized culture of COCCOII. They were not identified, and it is not known whether or not the growth of COCCOII was due to the release of $\mathrm{NH}_{4}{ }^{+}$or hydrolysis of the albumin to amino acids by the bacteria.

To ensure that the growth of organisms on the various amino acids was not due to contamination or other artifacts, the incorportation of ${ }^{15} \mathrm{~N}$ label from L-aspartic acid $\left({ }^{15} \mathrm{~N}-98\right.$ atom\%) was measured for COCCOII and PRYM. Incorporation occurred at rates similar to those for the oxidation of amino acids (see also Palenik \& Morel 1990).

The kinetics of $\mathrm{H}_{2} \mathrm{O}_{2}$ production from various amino acids was investigated for COCCOII, PRYM, and AMPHID. The initial rates of $\mathrm{H}_{2} \mathrm{O}_{2}$ production were investigated as a function of amino acid concentration for L-alanine, L- $\alpha$-aminobutyrate (PRYM only), Laspartate, L-glutamate, and L-serine. These results are shown in Fig. 5, 6, and 7. The half-saturation concentrations for L-alanine, L-glutamate, and L- $\alpha$ aminobutyrate were ca $0.2 \mu \mathrm{M}$ (range 0.1 to 0.5 ) for the 3 organisms. The half-saturation concentrations for Laspartic acid were higher for all organisms, at 1, 2, and $2 \mu \mathrm{M}$ for COCCOII, PRYM, and AMPHID, respectively. Since the data do not always conform to MichaelisMenten kinetics due to diffusion limitation (Palenik \& Morel 1990) and perhaps nonsteady state effects due to the enzyme itself, the use of linear transformation and regression analysis would be inappropriate. Instead the half-saturation 'concentration' was estimated as the concentration that yielded approximately a half-saturated hydrogen peroxide production rate.

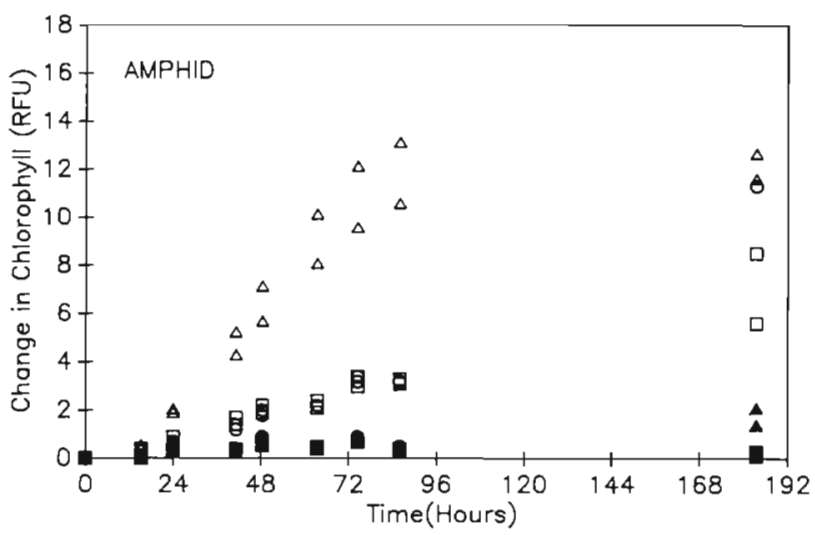

Fig. 3. Growth of AMPHID after $50 \mu \mathrm{M}$ amino acid or $0.01 \mathrm{mg}$ $\mathrm{ml}^{-1}$ BSA additions to nitrogen-limited cultures. Symbols as for Fig. 2 


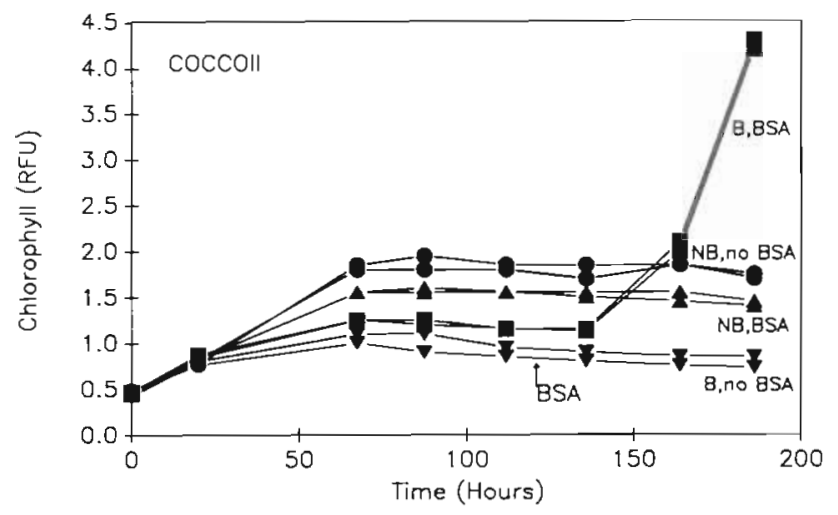

Fig. 4. Growth of COCCOII (as chlorophyll) with and without bacteria after addition of $0.006 \mathrm{mg} \mathrm{ml}^{-1}$ BSA to nitrogenlimited cultures: $(\bullet)$ no bacteria, no protein; ( $\mathbf{\Lambda}$ ) no bacteria, protein; ( $\mathbf{})$ bacteria, no protein; ( $\mathbf{-}$ ) bacteria, protein
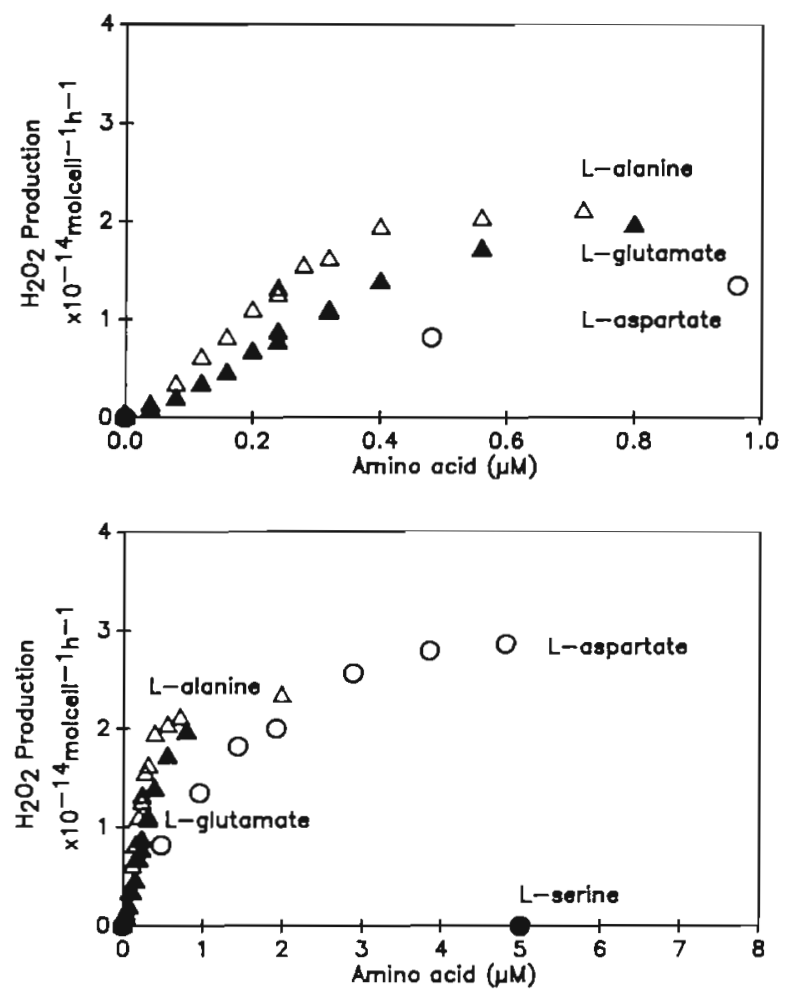

Fig. 5. Initial rates of $\mathrm{H}_{2} \mathrm{O}_{2}$ production by COCCOIl at varying arnino acid concentrations. ( $\angle$ ) L-alanıne; ( $\mathbf{1}$ ) L-glutamate; $(0)$ $\mathrm{L}$-aspartate; $(\bullet) \mathrm{L}$-serine. Figures show the same data at different amino acid concentration scales

At $5 \mu \mathrm{M}$ concentration, AMPHID and PRYM, but not COCCOII, showed slow but detectable rates of $\mathrm{H}_{2} \mathrm{O}_{2}$ production from L-serine. PRYM oxidized serine at rates that provided significant ammonia for growth (Fig. 2). Serine or its oxidation product hydroxypyruvate was not irreversibly inhibiting the active site of COCCOII (as a suicide substrate), a possible mechan-
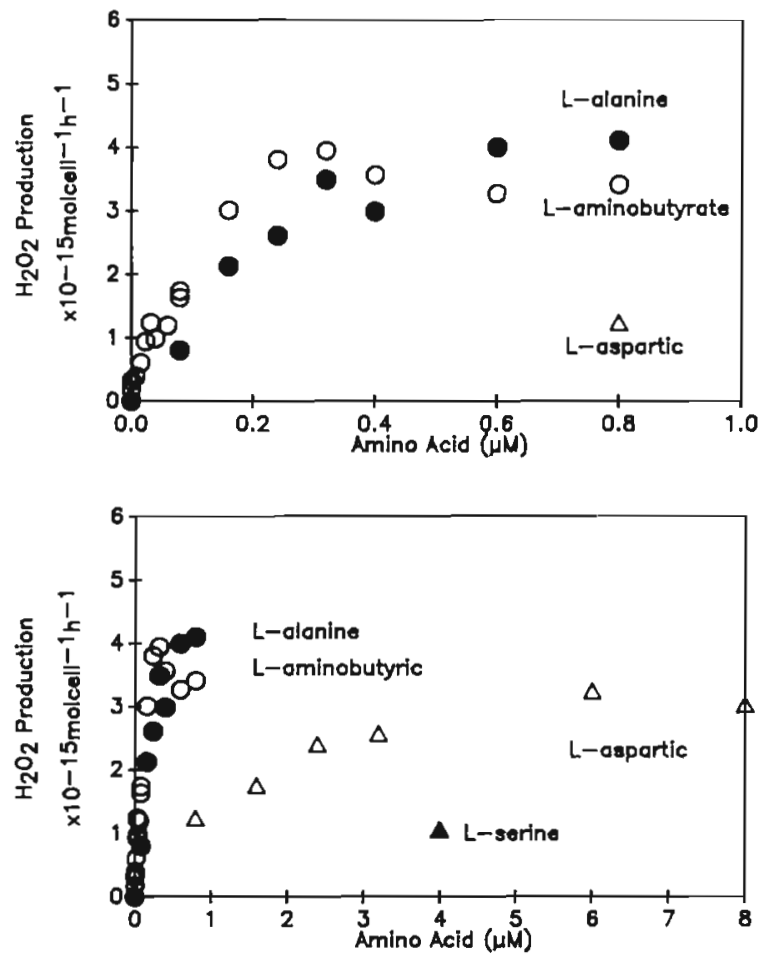

Fig. 6. Initial rates of $\mathrm{H}_{2} \mathrm{O}_{2}$ production by PRYM at varying amino acid concentrations. ( $\bullet$ L-alanine (O) L-aminobutyrate; $(\Delta)$ L-aspartate $(\Delta)$ L-serine. Figures show the same data at different amino acid concentration scales
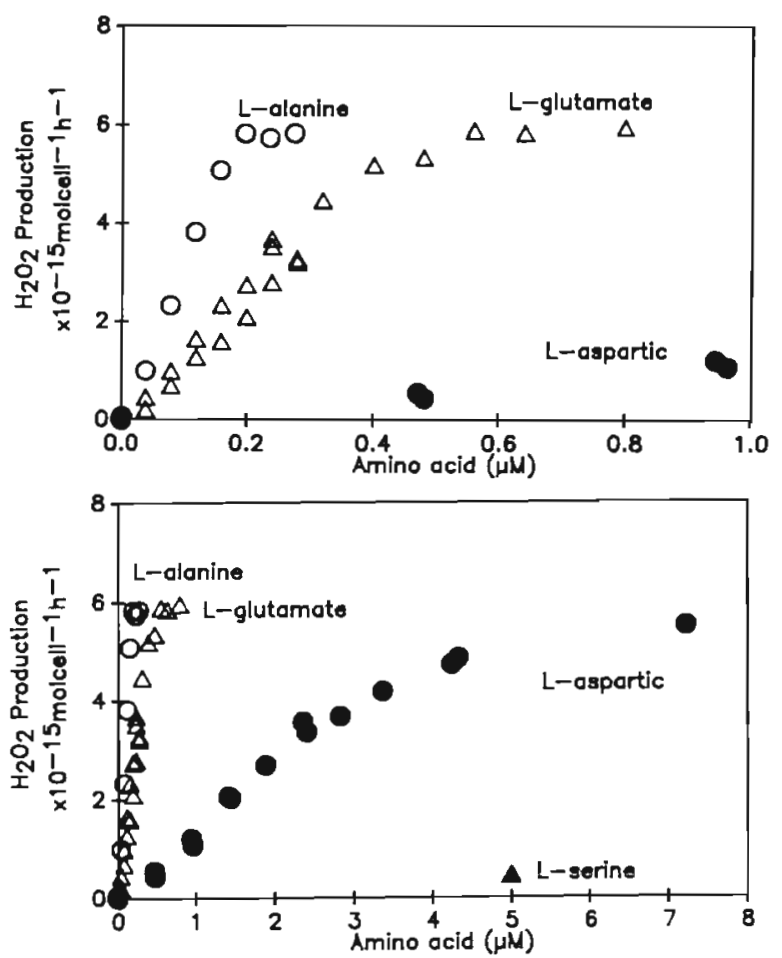

Fig. 7 Initial rates of $\mathrm{H}_{2} \mathrm{O}_{2}$ production by AMPHID at varying amino acid concentrations. (0) L-alanine; (L) L-glutatmate; $(\bullet)$ L-aspartate; (4) L-serine. Figures show the same data at different amino acid concentration scales 
ism for the lack of serine oxidation by this enzyme. These results indicate that although the L-amino acid oxidases are quite similar, some subtle distinctions exist in the characteristics of their active sites

Treatment of COCCOII with the nonspecific protease, proteinase $\mathrm{K}$, inactivated ( 80 to $100 \%$ inhibition) the cell-surface L-amino acid oxidase (Palenik \& Morel 1990). Treatment of PRYM cultures under similar conditions $\left(0.1 \mathrm{mg} \mathrm{m}^{-1}\right.$ for $15 \mathrm{~min}$ followed by dilution and centrifugation to collect the cells) had no effect on the oxidase activity (Fig. 8), Treatment of AMPHID cultures with proteinase $\mathrm{K}$ had some effect on oxidase activity (ca $40 \%$ inhibition). It seems that the oxidases of PRYM and AMPHID are less 'exposed' than that of COCCOII; they may have sugar residues covalently attached to exposed amino acids on the protein (glycosylation), for example, that protect these sites from proteases. Treatment of PRYM with DABS (diazobenzenesulfonic acid), another cell surface inhibitor, appeared to lyse the cells and was not used further.

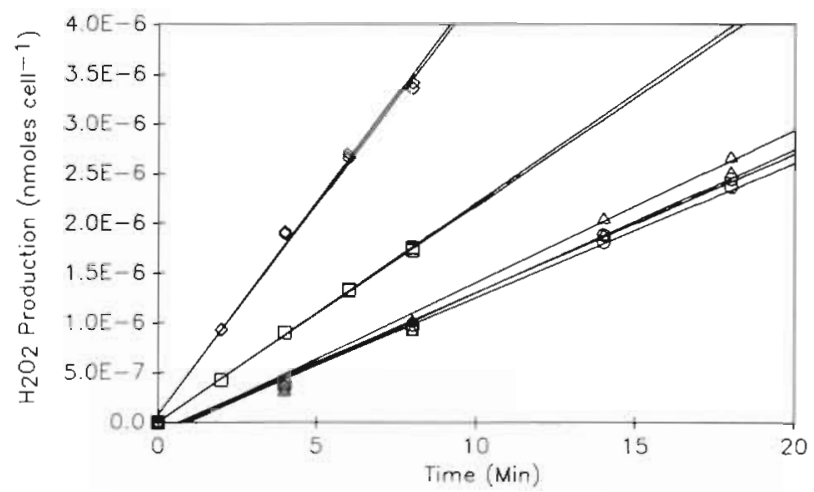

Fig. 8. Effect of proteinase $K$ treatment on AMPHID and PRYM whole cell amino acid oxidase activity. AMPHID: $(\square)$ prot. k treated; $(0)$ untreated. PRYM: $(\Delta)$ prot. k treated; (0) untreated. The $\mathrm{H}_{2} \mathrm{O}_{2}$ production is normalized to cell concentration. Linear regression lines are drawn through the data

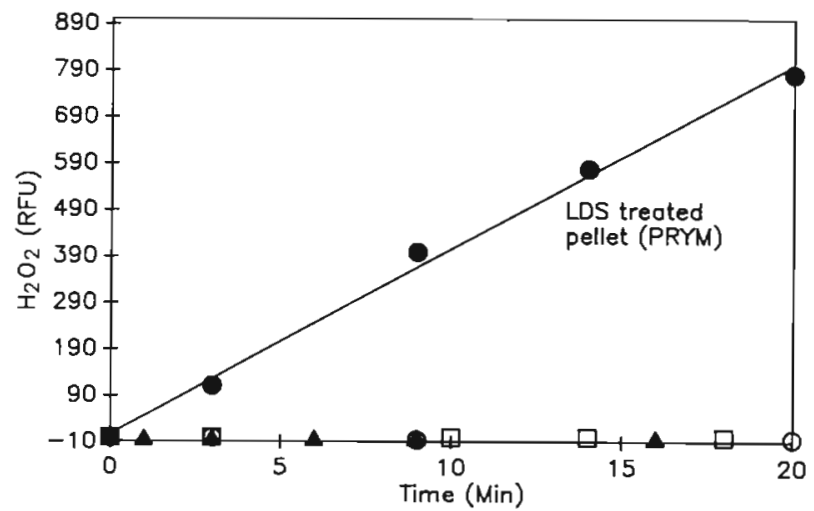

Fig. 9. Effect of $1 \%$ LDS treatment and ultracentrifugation on amino acid oxidase activity. PRYM: (•) $10 \mu \mathrm{l}$ pellet; (o) $50 \mu \mathrm{l}$ supernatant. AMPHID: (4) $10 \mu$ pellet; ( 50 ) 50 supernatant. Linear regression lines are drawn through the data
After treatment of PRYM with the detergent lithium dodecyl sulfate (LDS; $1 \%$ ), followed by high speed centrifugation $(120000 \times \mathrm{g}, 1.5 \mathrm{~h})$, the L-amino acid oxidase activity was present in the pellet fraction (Fig. 9). Treatment of COCCOII in a similar manner also resulted in activity in the pellet only. These results indicate that the enzyme in these organisms is either cell wall or membrane bound, and that it is also stable in $1 \%$ LDS, a treatment that denatures most proteins. For AMPHID, however, $1 \%$ LDS treatment destroyed oxidase activity (Fig. 9).

L-amino acid oxidase activity has been found in 3 phytoplankton genera to date: Pleurochrysis, Prymnesium, and Amphidinium. The enzyme activity in these organisms was investigated under conditions of excess nitrate (f/10; $\mathrm{NO}_{3}{ }^{-}$exponential phase, batch culture), under nitrogen-limited conditions, and in cells grown in excess ammonia (f/10; $\mathrm{NH}_{4}{ }^{+}$exponential phase, batch culture). Table 1 summarizes the saturated rate constants for L-amino acid oxidase activities, typically assayed with $20 \mu \mathrm{M}$ L-alanine, for various organisms under the different nitrogen regimes.

The Amphidinium species tested showed oxidase activity only under nitrogen-limited conditions. AMPHID had a much higher activity (per cell) than AMPHI. Prymnesium calathiferum also showed activity only under nitrogen-limited conditions, and the activity was quite low. In $P$. parvum the enzyme was expressed under excess nitrate and nitrogen-limited conditions; there was little enhancement of enzyme activity as cells became nitrogen limited. Pleurochrysis carterae also showed enzyme activity under excess nitrate conditions and its Vmax increased several-fold under nitrogen limitation. No organism showed oxidase activity when growing in the presence of excess ammonia.

Table 1. Saturated rate constants (Vmax; $\times 10^{-13} \mathrm{~mol} \mathrm{cell}{ }^{-1}$ $\mathrm{h}^{-1}$ ) for L-amino acid oxidases from several phytoplankton grown in excess ammonia $\left(\mathrm{NH}_{4}^{+}\right)$, excess nitrate $\left(\mathrm{NO}_{3}^{-}\right)$and nitrogen-limited $\left(\mathrm{N}_{\mathrm{l}, \mathrm{m}}\right)$ conditions. The rates are averages of 2 or more measurements of the saturated rate constant, assayed using L-alanine $(20 \mu \mathrm{M})$. The coefficient of variation of replicate cultures was found previously to be about $23 \%$

\begin{tabular}{lcccc}
\hline Organism & $\mathrm{NH}_{4}^{+}$ & $\mathrm{NO}_{3}^{-}$ & $\mathrm{N}_{\mathrm{lim}}$ \\
\hline Amphidinium carterae (AMPHI) & $\mathrm{ND}$ & $\mathrm{ND}$ & 1.3 \\
Amphidinium operculatum (AMPHID) & $\mathrm{ND}$ & $\mathrm{ND}$ & 8.5 \\
Pleurochrysis carterae (COCCOII) & $\mathrm{ND}$ & 12 & $30-56$ \\
Prymnesium parvum (PRYM) & $\mathrm{ND}$ & 6.5 & 7.3 \\
Prymnesium calathiferum (CHANGl) & - & $\mathrm{ND}$ & 0.1
\end{tabular}

ND: not detectable. The detection limit varies with the number and type of cell assayed and fluorometer stability, but in our case was ca $0.5 \times 10^{-16} \mathrm{~mol}$ cell h $\mathrm{h}^{-1}$

-: not assayed 


\section{DISCUSSION}

The presence of L-amino acid oxidase activity in 3 separate phytoplankton genera suggests its ecological importance, particularly in nearshore environments where these organisms are found. The oxidases of the 3 organisms studied in detail appear to be quite similar, especially given the evolutionary distances separating dinoflagellates (AMPHID, AMPHI) and prymnesiophytes (COCCOII, PRYM, and CHANG1). They have half-saturation concentrations of about $0.2 \mu \mathrm{M}(0.1$ to $0.45 \mu \mathrm{M}$ range) for the 'ideal' amino acid substrates where the $\mathrm{R}$ group is $-\mathrm{CH}_{2}(\mathrm{H}),-\mathrm{CH}_{2}\left(\mathrm{CX}_{3}\right)$, but not $\mathrm{CH}_{2}(\mathrm{OH})$. Individual amino acid concentrations and total abundances can vary greatly, but the common amino acids likely to be oxidized by this enzyme in the environment are L-alanine, L-glutamate, L-leucine, Llysine, and L-ornithine. Together these would be about 30 to $50 \%$ of the total amino acid concentration or about $0.1 \mu \mathrm{M}$ (Garrasi et. al 1979). L-aspartic acid has a higher half-saturation concentration for the oxidase, but in some environments will still be an important nitrogen source because of its relative abundance.

Two common amino acids in natural waters, L-serine $\left(\mathrm{R}=\mathrm{CH}_{2} \mathrm{OH}\right)$ and glycine $(\mathrm{R}=\mathrm{H})$, are not effective substrates. On the one hand this is puzzling, because one would expect the oxidases to have evolved to utilize common amino acids. If however, phytoplankton amino acid oxidases control amino acid distributions in natural waters, then glycine and serine concentrations would be high because they are not oxidized by these enzymes. While previous research on the uptake of radio-labelled amino acids suggested that bacteria control amino acid concentrations (e.g. Hollibaugh 1976. Hoppe 1976), the results reported here reopen the question of the relative importance of bacterial or phytoplankton utilization of amino acids in different ocean regimes.

When one looks closely, there are clearly differences among the enzymes of the various genera. AMPHID and PRYM oxidize L-serine at slow but detectable rates, while COCCOII does not. Similarly, the oxidase of COCCOII shows a higher affinity (lower $\mathrm{Km}$ ) for Laspartic acid than the other 2 enzymes. Since L-serine and L-aspartic acid vary by substitutions at the betacarbon, it appears that these differences reflect variations in the active site. The enzymes also show different sensitivities to treatment with proteinase $K$ or LDS (Figs. 8 and 9). These differences are likely to reflect differences in higher order structure or protection by glycosylation.

Phytoplankton regulate the expression of their Lamino acid oxidase depending on the nitrogen conditions of the medium (Table 1). The nitrogen-limited conditions in our experiments were obtained at the beginning of the plateau phase in (nitrogen-limited) batch cultures. These conditions are useful for testing phytoplankton cultures for the presence of the oxidase. It would be instructive to utilize continuous cultures with varying $\mathrm{NO}_{3}^{-}, \mathrm{NH}_{4}{ }^{+}$, and amino acid ratios to ascertain under what precise conditions the amino acid oxidases are synthesized.

Given our previous results with Pleurochrysis species and isolates, and the comparison of the 2 Amphidinium and the 2 Prymnesium species reported here, it seems that within any phytoplankton genus with the enzyme, a range of regulation patterns will be found. These patterns would presumably be due to evolutionary pressures associated with the organic nitrogen (amino acid) conditions in the specific organism's environment.

None of the organisms tested could use high concentrations of bovine serum albumin as a nitrogen source except in the presence of bacteria. COCCOII can utilize $\mathrm{N}$-terminal glycines on peptides, however (Palenik 1989). The organisms with amino acid oxidases thus do not possess cell-surface or soluble extracellular proteases that would convert protein to amino acids and thus enhance the amino acid concentrations at cell-surfaces. Such proteases have been reported in only a few phytoplankton such as Ochromonas and Nitzschia (Pringsheim 1951, 1952), however their presence has not been thoroughly investigated

Marine bacteria have been shown to have cell-surface or soluble proteases (e.g. Amano et al. 1982), and extracellular proteases have been detected in the environment (e.g. Hoppe et al. 1988). However, the contribution of protein hydrolysis by these enzymes to the pool of free amino acids relative to other processes such as excretion is unknown. The work of Hollibaugh \& Azam (1983) suggests that the amino acids and peptides from bacterial proteolysis may be taken up too rapidly to equilibrate with the soluble pool. In any case a range of interactions between phytoplankton and bacteria may occur in natural waters, perhaps some involving competition for amino acids derived from bacterial proteolysis. Others may involve cooperative interactions in which bacteria hydrolyze proteins to recycle nitrogen for the phytoplankton, and phytoplankton produce $\alpha$-ketoacids and other exudates for bacteria. For this reason, the growth of bacterized cultures of COCCOII on BSA (Fig. 4) is intriguing

The major portion of dissolved organic nitrogen is neither free nor combined amino acids, but is uncharacterized (Sharp 1983). Recent reports suggest that this pool is even larger than previously estimated (Suzuki \& Sugimura 1985). The importance of cellsurface enzymes or cell-surface catalyzed mechanisms for breaking down these nitrogen forms should not be 
overlooked. These mechanisms, if they exist, could enhance the cell-surface concentration of primary amines and ammonia beyond that of the bulk solution.

Cell-surface L-amino acid oxidases have been found in 2 prymnesiophyte and 1 dinoflagellate genera. The presence of amino acid oxidases, possibly cell-surface, in some chlorophytes is likely, if the early work of Algeus (1948a,b) is correct. His results suggested that Scenedesmus species might be deaminating glycine extracellularly. A D-amino acid oxidase (location unknown) may occur in Chlorella species (Wikstroem et al. 1982). From the results to date, diatoms appear to have amino acid transport systems (reviewed in Flynn $\&$ Butler 1986) rather than oxidases. Prokaryotic phytoplankton (Synechococcus) could potentially have cellsurface oxidases; they are already known to have internal ones (Meyer \& Pistorius 1987). Our preliminary testing of these organisms, however, was inconclusive. Since many phytoplankton are brought into culture by enriching with inorganic nitrogen sources, culture collections may be biased against species with oxidases or deaminases in general. The potential buildup of $\mathrm{H}_{2} \mathrm{O}_{2}$ and $\alpha$-keto acids with large amino acid enrichments may also be a problem. Finding additional species with amino acid oxidases should thus involve both screening existing culture collections and the isolation of new species by gradual amino acid enrichments of natural samples. The 3 phytoplankton genera discussed here are likely to represent only some of the possible variations on the common theme of cell-surface deamination.

Acknowledgements. We thank D. J. Kieber for assistance with the $\alpha$-keto acid measurements. C. Lee, P. Gschwend, N. V Blough, O. C. Zafiriou, S. W Chisholm, and J. Stegeman kindly provided comments on the manuscript. Funding was provided by ONR Contract N-00014-80-C-0273 and NSF Grant OCE83-17532

\section{LITERATURE CITED}

Algeus, S. (1948a). Glycocoll as a source of nitrogen for Scenedesmus obliquus. Physiol plant. 1: 65-84

Algeus, S. (1948b). The deamination of glycocoll by green algae. Physiol. plant. 1. 382-386

Amano, M., Hara, S., Taga, N. (1982). Utilization of dissolved amino acids in seawater by marine bacteria. Mar. Biol. 68: 31-36

Brand, L. E., Sunda, W. G., Guillard, R. R. L. (1983). Limitation of marine phytoplankton reproduction rates by zinc, manganese, and iron. Limnol. Oceanogr. 28: 1182-1198

Flynn, K. J., Butler, I. (1986). Nitrogen sources for the growth of microalgae: role of dissolved free amino acids. Mar. Ecol. Prog. Ser. 34: 281-304

Garrasi, C., Degens, E. T., Mopper, K. (1979). The free amino

This article was submitted to the editor acid composition of seawater obtained without desalting and preconcentration. Mar. Chem. 8: 71-85

Guillard, R. R. L., Ryther, J. H. (1962). Studies on marine planktonic diatoms I. Can. J. Microbiol. 8: 229-239

Hollibaugh, J. T (1976). The biological degradation of arginine and glutamatic acid in seawater in relation to the growth of phytoplankton. Mar Biol. 36: 303-312

Hollibaugh, J. T., Azam, F. (1983). Microbial degradation of dissolved proteins in seawater Limnol Oceanogr. 28 $1104-1116$

Hoppe, H.-G. (1976). Determination and properties of actively metabolizing heterotrophic bacteria in the sea, investigated by means of microautoradiography. Mar Biol. 62 : $125-129$

Hoppe, H.-G., Kim, S.-J., Gocke, K. (1988). Microbial decomposition in aquatic environments: combined process of extracellular enzyme activity and substrate uptake. Appl. environ. Microbiol. 54: 784-790

Keller, M. D., Bellows, W K., Guillard, R. R. L. (1988). Microwave treatment for sterilization of phytoplankton culture media. J. exp. mar Biol. Ecol. 117: 279-283

Kieber, D. J., Mopper, K. (1986). Trace determination of $\alpha$ keto acids in natural waters. Analyt. Chim. Acta 183: $129-140$

Kuenzler, E. J., Perras, J. P. (1965). Phosphatases of marine algae. Biol. Bull. mar biol. Lab., Woods Hole. 128: 271-284

McLaughlin, J. J., Zahl, P. A. (1959). Studies in marine biolagy. 3. Axenic zooxanthellae from various invertebrate hosts. Ann. N.Y Acad. Sci. 77: 55-72

Meyer, R., Pistorius, E. K. (1987). Some properties of photosystem II preparations from the cyanobacterium Synechococcus sp.: the presence of an L-amino acid oxidase. Biochim. Biophys. Acta 893: 426-433

Palenik, B. (1989). Organic nitrogen utilization by phytoplankton: the role of cell-surface deaminases. Ph. D. thesis, MIT/ WHOI, WHOI-89-18

Palenik, B., Morel, F. M. M. (1988). Dark production of hydrogen peroxide in the Sargasso Sea. Limnol. Oceanogr 33: $1606-1611$

Palenik, B., Morel, F. M. M. (1990). Amino acid utilization by marine phytoplankton: a novel mechanism. Limnol. Oceanogr. (in press)

Pringsheim, E. G. (1951). Uber farblose Diatomeen. Arch. Mikrobiol. 16: 18-27

Pringsheim, E. G. (1952). On the nutrition of Ochromonas. $Q$ J. microsc. Sci. 93: 71--96

Sharp, J. (1983). The distributions of inorganic nitrogen and dissolved and particulate organic nitrogen in the sea. In: Carpenter, E. J., Capone, D. G. (eds.) Nitrogen in the marine environment. Academic Press, New York, p. 1-35

Suzuki, Y., Sugimura, Y. (1985). A catalytic oxidation method for the determination of total nitrogen dissolved in seawater. Mar. Chem. 16: 83-97

Turner, M. F. (1979). Nutrition of some microalgae with special reference to vitamin requirements and utilization of nitrogen and carbon sources. J. mar. biol. Ass. U.K. 59. 535-552

Wheeler, P. A., North, B. B., Stephens, G. C. (1974). Amino acid uptake by marine phytoplankters. Limnol. Oceanogr. 19: $249-258$

Wikstroem, P., Szwajcer, E., Brodelius, P., Nilsson, K., Mosbach, K. (1982). Formation of $\alpha$-keto acids from amino acids using immobilized bacteria and algae. Biotechnol. Lett. 4: 153-158

Manuscript first received: July 11, 1989 Revised version accepted: September 19, 1989 